\title{
Comparison of serum prohepcidin and iron metabolism parameters in obese and non-obese elderly individuals
}

\author{
Porównanie surowiczej prohepcydyny i parametrów metabolizmu żelaza \\ u osób w podeszłym wieku z otyłością oraz bez otyłości \\ Justyna Przybyszewska' ${ }^{1}$ Ewa Żekanowska ${ }^{2}$, Kornelia Kędziora-Kornatowska ${ }^{3}$, Joanna Boinska², \\ Katarzyna Porzych ${ }^{3}$, Michat Przybyszewski ${ }^{4}$, Roman Cichon ${ }^{1}$ \\ ${ }^{1}$ Department of Nutrition and Dietetics, Nicolaus Copernicus University in Torun, Collegium Medicum in Bydgoszcz, Poland \\ ${ }^{2}$ Department of Pathophysiology, Nicolaus Copernicus University in Torun, Collegium Medicum in Bydgoszcz, Poland \\ ${ }^{3}$ Department and Clinic of Geriatrics, Nicolaus Copernicus University in Toruń, Collegium Medicum in Bydgoszcz, Poland \\ ${ }^{4}$ Clinic of Allergology, Clinical Immunology and Internal Diseases, Nicolaus Copernicus University in Toruń, Collegium Medicum \\ in Bydgoszcz, Poland
}

\begin{abstract}
Introduction: Current knowledge indicates that there is a close connection between being overweight, obesity and iron metabolism disorders, but the underlying mechanism is unclear. Hepcidin could be a major contributor to poor iron status observed in the obese population. Material and methods: The study was performed in 58 obese elderly individuals (F/M 34/24) aged 65-91 (78.92 \pm 8.32) years. The control group consisted of 15 non-obese elderly volunteers, age- and sex-matched. Based on the WHO definition, 36 (62\%) obese individuals were diagnosed with normo- or microcytic anaemia. The following parameters were determined: prohepcidin, haemoglobin, serum iron, erythropoietin, ferritin and C-reactive protein (CRP).

Results: Prohepcidin concentrations were significantly increased in obese elderly individuals without anaemia compared to obese and anaemic $(\mathrm{p}<0.01)$ as well as non-obese volunteers $(\mathrm{p}<0.01)$. In obese individuals with anaemia there was a decrease in serum iron, concomitant with increased levels of erythropoietin and CRP compared to two other groups. Ferritin concentration was increased in obese people (with and without anaemia) compared to the non-obese group. Serum prohepcidin levels were positively correlated with fat mass percentage in obese individuals without and with anaemia $(r=0.32 ; p=0.02)$.

Conclusion: Results of this preliminary study suggest that body fat content does have an impact on prohepcidin concentration, and thereby on iron homeostasis. (Endokrynol Pol 2013; 64 (4): 272-277)
\end{abstract}

Key words: iron metabolism, obesity, prohepcidin

\section{Streszczenie}

Wstęp: Obecny stan wiedzy wskazuje na ścisły związek pomiędzy nadwagą czy otyłością a zaburzeniami metabolizmu żelaza. Jednakże mechanizm tej zależności nie jest wyjaśniony. Hepcydyna może byćistotnym czynnikiem niedoborów żelaza obserwowanych w populacji osób otyłych. Materiał i metody: Badanie zrealizowano wśród 58 otyłych osób (K/M 34/24), w wieku 65-91 lat (78,92 \pm 8,32 lat). Grupę kontrolną stanowiło 15 zdrowych ochotników z prawidłową masą ciała, dobranych odpowiednio pod względem wieku i płci. Na podstawie definicji WHO, u 36 (62\%) otyłych pacjentów zdiagnozowano niedokrwistości normo lub mikrocytową. W ramach badań oznaczono następujące parametry: prohepcydynę, hemoglobinę, stężenie żelaza, ferrytyny i erytropoetyny, białka C-reaktywnego (CRP).

Wyniki: Wykazano istotnie wyższe stężenie surowiczej prohepcydyny w grupie pacjentów otyłych bez niedokrwistości $(p<0,01)$ w porównaniu z wartościami obserwowanymi u pacjentów otyłych z niedokrwistością oraz u osób z grupy kontrolnej z prawidłową masą ciała $(p<0,01)$. U osób otyłych z niedokrwistością, obserwowano obniżone stężenie żelaza przy jednocześnie podwyższonych wartościach erytropoetyny oraz białka CRP w porównaniu z pozostałymi dwoma analizowanymi grupami. Stężenie ferrytyny było wyższe u pacjentów otyłych (zarówno z niedokrwistością oraz bez niedokrwistości) w odniesieniu do osób bez cech otyłości. W grupie pacjentów otyłych zarówno z niedokrwistością jak też bez niedokrwistości surowicza prohepcydyna pozytywnie korelowała z procentową zawartością tkanki tłuszczowej $(\mathrm{r}=0,32 ; \mathrm{p}=0,02)$.

Wnioski: Wyniki wstępnych badań sugerują, że tkanka tłuszczowa może mieć wpływ na stężenie surowiczej prohepcydyny a tym samym również na ogólnoustrojową homeostazę żelaza. (Endokrynol Pol 2013; 64 (4): 272-277)

Słowa kluczowe: metabolizm żelaza, otyłość, prohepcydyna

\section{Introduction}

Current knowledge indicates that there is a close connection between being overweight, obesity and iron metabolism disorders, but the underlying mechanism is unclear [1-6]. It has been noticed that the diet of obese people consists mainly of high fat and high carbohydrate meals with low value of Index of Nutritional 
Quality [INQ] for iron [7, 8]. Moreover, the hypoferremia development in obese individuals could be a consequence of obesity-associated low-grade inflammation $[9,10]$. Adipose tissue is a very active endocrine organ secreting numerous hormones and cytokines associated with important systemic effects on different metabolic processes $[9,10]$. Studies available in the literature indicate that adipose tissue of obese patients produced an increased amount of proinflammatory cytokines contributing to the development of a lowgrade systemic inflammation in these patients $[7,10]$.

Research by Bekri et al. [5] pointed out that adipocytes are the direct source of hepcidin, a peptide made up of 25 amino acids that plays a central role in the regulation of iron homeostasis. The major action of hepcidin is to internalise and degrade the iron efflux transporter ferroportin expressed on all iron-exporting cells [11]. So, a high hepcidin level leads to the suppression of intestinal iron absorption and iron release from macrophages and hepatocytes, whereas a low concentration of hepcidin leads to acceleration of iron release from these cells [11-16]. As a result, increased hepcidin production may cause sideropenia $[15,16]$. Hepcidin is a peptide synthesised mainly in the liver [17-19]. Hepatic hepcidin gene expression is more responsive to changes in erythropoiesis activity or iron intake rather than to changes in body iron stores [20-22]. It remains unknown whether the same regulatory factors also control the 'adipose tissue-derived pool of hepcidin'. Recent studies indicate that IL-6, leptin and other inflammatory mediators may increase hepcidin concentration in human serum through the JAK2/ /STAT3 signalling pathway [6, 23]. Obesity-related low grade inflammation followed by increasing hepcidin concentration may reduce iron bio-availability [18-19]. Therefore, hepcidin could be a major contributor to poor iron status observed in the obese population.

The aim of this work was to compare serum prohepcidin and iron metabolism parameters in obese and non-obese elderly individuals.

\section{Material and methods}

The study group consisted of 58 obese elderly individuals (24 males, 34 females) between 65 and 91 years of age (mean age of $78.92 \pm 8.32$ ) admitted to the Department and Clinic of Geriatrics, Nicolaus Copernicus University in Torun, Collegium Medicum in Bydgoszcz. Obesity was defined as a fat mass percentage (\%FM) $\geq 25 \%$ in males and $\geq 33 \%$ in females [24]. Men with a $\% \mathrm{FM}=17-25 \%$ and women with a $\% \mathrm{FM}=22-33 \%$ were classified as normal body fat content (non-obese). Based on the Hgb levels below $12 \mathrm{~g} / \mathrm{dL}$ in females and $13 \mathrm{~g} / \mathrm{dL}$ in males (WHO criteria), 36 obese individuals
$(62 \%)$ were diagnosed with normo- or microcytic anaemia. For this reason, the study group of obese individuals was divided into two subgroups: Group I - obese, without anaemia $\mathrm{N}=22$, and Group II - obese, with anaemia $\mathrm{N}=36$.

The peripheral blood samples were taken after the diagnosis of anaemia had been made, but prior to treatment being provided.

The control group consisted of 15 healthy non-obese elderly volunteers (F/M 9/6) between 55 and 78 years of age (mean age of $66.57 \pm 8.81$ ), who came to the outpatient geriatric clinic in order to perform a complex geriatric examination (Group III).

We excluded from the control group those people who had chronic inflammatory diseases and patients with: anaemia, undernutrition, cancer, rheumatic disorders, inflammatory bowel diseases, endocrine diseases and those treated with steroid or non-steroidal antiinflammatory drugs.

Anyone who had taken any vitamin or mineral supplements was excluded from the research.

All procedures in the study were approved by the Local Ethics Committee. Informed written consent was obtained after the purpose, nature, and potential risks had been explained to the subjects.

\section{Analytical methods}

Serum was stored at $-80^{\circ} \mathrm{C}$ until analyses. Levels of prohepcidin were determined by a stable enzyme-linked immunosorbent assay (ELISA) (DRG Instruments GmbH, Germany). Serum ferritin was quantified using the DRG Ferritin kit (EIA-1872, DRG International, Inc., USA). Serum erythropoietin was determined by the EPO ELISA kit (Roche Diagnostics GmbH, Mannheim, Germany).

Serum iron concentration was measured on the Architect c8000 System (Abbott Laboratories, IL, USA). $\mathrm{C}$-reactive protein concentration in serum was determined by using BN ${ }^{\mathrm{TM}}$ II Systems (Dade Behring). Haemoglobin concentration was analysed in the routine diagnostic by using the Sysmex XE-2100.

Nutritional status was carried out based on the measurements of body mass $(\mathrm{kg})$, body height $(\mathrm{cm})$ and thickness of four skinfolds (mm): over biceps (BSF), triceps (TSF), suprailiac (SISF) and subscapular (SCSF). The body mass measurement was carried out using a Radwag physician scale, with electronic reading scale and measurement accuracy of $0.01 \mathrm{~kg}$. Height was measured, and skinfolds thickness using a skinfold caliper made by Siber Hegner \& Co. Ltd (measurement accuracy of $0.1 \mathrm{~cm}$ ). The body mass index (BMI) was calculated by dividing the weight by the height squared $\left(\mathrm{kg} / \mathrm{m}^{2}\right)$. Fat mass percentage in the body $(\% \mathrm{FM})$ was calculated on the basis of weight measurements and the sum of four skinfolds thickness, according to the 
Table I. Prohepcidin and iron metabolism parameters in the study subgroups and control group

Tabela I. Prohepcydyna oraz parametry gospodarki żelazowej w badanych podgrupach oraz w grupie kontrolnej

\begin{tabular}{|c|c|c|c|c|}
\hline \multirow[t]{2}{*}{ Parameter* } & \multicolumn{2}{|c|}{ Study groups } & \multirow{2}{*}{$\begin{array}{c}\text { Control group } \\
\text { Non-obese } \\
\text { no anaemia } \\
\text { III (N = 15) }\end{array}$} & \multirow[t]{2}{*}{$\mathbf{p}$} \\
\hline & $\begin{array}{c}\text { Obese } \\
\text { no anaemia } \\
\text { I (N=22) }\end{array}$ & $\begin{array}{c}\text { Obese } \\
\text { with anaemia } \\
\text { II }(\mathrm{N}=\mathbf{3 6})\end{array}$ & & \\
\hline \multirow{3}{*}{$\begin{array}{l}\% \mathrm{FM} \\
(\%)\end{array}$} & $40.01 \pm 5.98$ & $36.32 \pm 5.34$ & $22.75 \pm 4.69$ & NS I-II \\
\hline & & & & 0.0261 II-III \\
\hline & & & & 0.0009 I-III \\
\hline \multirow{3}{*}{$\begin{array}{l}\text { BMI } \\
{[\mathrm{kg} / \mathrm{m} 2]}\end{array}$} & $31.86 \pm 4.75$ & $29.51 \pm 5.46$ & $26.28 \pm 1.67$ & NS I-II \\
\hline & & & & 0.0395 II-III \\
\hline & & & & 0.0182 I-III \\
\hline \multirow{3}{*}{$\begin{array}{l}\text { Haemoglobin } \\
{[\mathrm{g} / \mathrm{dL}]}\end{array}$} & $14.12 \pm 1.36$ & $10.81 \pm 1.49$ & $13.43 \pm 0.77$ & $<0.0001$ I-II \\
\hline & & & & $<0.0001$ II-III \\
\hline & & & & NS I-III \\
\hline Prohepcidin & 293.29 & 224.85 & 151.38 & 0.0033 I-II \\
\hline \multirow[t]{2}{*}{ [ng/mL] } & $(262.8 ; 370.7)$ & $(188.7 ; 240.4)$ & $(128.4 ; 241.7)$ & NS II-III \\
\hline & & & & 0.0005 I-III \\
\hline \multirow{3}{*}{$\begin{array}{l}\text { Iron } \\
{[\mu \mathrm{g} / \mathrm{dL}]}\end{array}$} & 80.95 & 35.00 & 80.00 & $<0.0001 \mathrm{I}-\mathrm{II}$ \\
\hline & (70.00; 98.00 & $(22.25 ; 62.70)$ & $(40.00 ; 106.0)$ & 0.0015 II-III \\
\hline & & & & NS I-III \\
\hline Ferritin & 41.72 & 57.48 & 11.40 & NS I-II \\
\hline \multirow[t]{2}{*}[\mathrm{ng}/\mathrm{mL}]{} & $(27.77 ; 75.5)$ & $(19.60 ; 134.6)$ & $(9.26 ; 15.70)$ & 0.0046 II-III \\
\hline & & & & 0.0151 I-III \\
\hline \multirow{3}{*}{$\begin{array}{l}\text { EPO } \\
{[\mathrm{U} / \mathrm{L}]}\end{array}$} & 4.74 & 8.95 & 3.68 & 0.0277 I-II \\
\hline & $(3.76 ; 8.11)$ & $(5.36 ; 13.87)$ & $(1.76 ; 5.60)$ & 0.0024 II-III \\
\hline & & & & NS IVIII \\
\hline \multirow{3}{*}{$\begin{array}{l}\text { CRP } \\
{[\mathrm{mg} / \mathrm{L}]}\end{array}$} & 3.19 & 8.85 & 3.0 & 0.0012 I-II \\
\hline & $(3.00 ; 5.00)$ & $(5.50 ; 41.90)$ & $(3.0 ; 3.09)$ & $<0.0001$ II-III \\
\hline & & & & NS I-III \\
\hline
\end{tabular}

${ }^{*}$ Results are reported as mean \pm SD (standard deviation) or medians $(01 ; 03) 01$ and $03-25^{\text {th }}$ and $75^{\text {th }}$ percentiles. $\mathrm{p}$ - significance level; $\mathrm{N}$ - sample size; NS differences not significant; \% FM — fat mass percentage; $\mathrm{BMI}$ — body mass index; $\mathrm{EPO}$ - erythropoietin; $\mathrm{CRP}$ — C-reactive protein

Durnin and Wormsley formula [25]. The values of somatic parameters were interpreted for each person individually according to sex with reference [24, 25].

\section{Statistical analysis}

All statistics were conducted using Statistica software, version 8.0 (Stat-soft, Krakow, Poland). The normal distribution of variables was evaluated using W-ShapiroWilk test. Results are presented as mean \pm standard deviation (SD) when the data demonstrated a normal distribution, or as medians $\left[\mathrm{Q}_{1}\right.$ (lower quartile) to $\mathrm{Q}_{3}$ (upper quartile)] due to their being abnormally skew of the data. The following statistical tests were used in the study: one-way ANOVA and post-hoc tests. The relationships between the examined parameters were determined by Spearman's rank-order correlation. A p value of $<0.05$ was considered statistically significant.

\section{Results}

There were non-significant differences in levels of haematological and biochemical parameters between all the study groups as regards sex $(p>0.05)$. Therefore, the study results do not take into account the statistical distribution of sex. As expected, mean values of the fat mass percentage in the body $(\% \mathrm{FM})$ were significantly higher in the obese elderly patients (with anaemia and without anaemia) compared to healthy non-obese controls. Similarly, mean BMIs were significantly greater in the obese groups (with anaemia and without anaemia) compared to the controls. The haemoglobin concentration in obese patients with anaemia was the lowest among all groups (Table I).

In our study we demonstrated that prohepcidin concentrations were significantly increased in obese elderly 
individuals without anaemia (Group I) $(\mathrm{Me}=293.29$ $\mathrm{ng} / \mathrm{mL}$ ) compared to obese and anaemic individuals (Group II) (Me $=224.85 \mathrm{ng} / \mathrm{mL}$ ) as well as non-obese volunteers (Group III) $(\mathrm{Me}=151.38 \mathrm{ng} / \mathrm{mL})$. There were non-significant differences between obese patients with anaemia and non-obese controls regarding prohepcidin levels ( $\mathrm{p}>0.05)$.

Both EPO and CRP were significantly higher in elderly obese patients with anaemia (Group II) compared to the obese non-anaemic patients as well as the controls (Table I). No significant difference in serum $\mathrm{EPO}$ and CRP concentrations was found between obese non-anaemic and non-obese non-anaemic patients. Similarly, no statistically significant difference in iron concentrations was found among these two groups (I and III). The concentration of iron was the lowest in the group of obese patients with anaemia. Elevated ferritin levels were found in the patients with obesity (with anaemia $(57.48 \mathrm{ng} / \mathrm{mL}$ ) and without anaemia $(41.72 \mathrm{ng} / \mathrm{mL})$ compared to non-obese individuals $(11.40 \mathrm{ng} / \mathrm{mL})$ (Table I).

In the whole group of obese individuals, with and without anaemia, serum prohepcidin levels were positively correlated with fat mass percentage $(\mathrm{r}=0.32$; $\mathrm{p}=0.02$ ) (Fig. 1). In the group of non-obese elderly patients, prohepcidin was not related to any parameters studied.

\section{Discussion}

Obesity is defined as an excess of body fat, which increases the risk of many diseases and premature mortality. Currently, the most commonly used diagnostic indicator of obesity is body mass index (BMI). In addition, BMI has been widely used and accepted as a simple method to classify medical risk by weight status. The results show that BMI provides a measure of the relation between height and weight and correlates with body fat percentage in young and middle-aged adults [26-28]. In elderly people, age-related changes in body composition (i.e. decrease in lean body mass and increase in fat mass) and loss of height caused by compression of vertebral bodies and kyphosis [26, 28-29] alter the relation between BMI and percentage body fat. In addition, especially for those in late old age and / or very late or hospitalised patients, are observed disturbances in water and electrolyte balance. In view of this, we must remember that dehydration will affect weight loss and decrease in BMI. On the contrary, hyperhydration, which may be the result of, inter alia, too intensive fluid therapy, will increase BMI value. Therefore, changes in body composition would tend to underestimate fatness, whereas the loss of height would tend to overestimate fatness. Therefore, in our study,

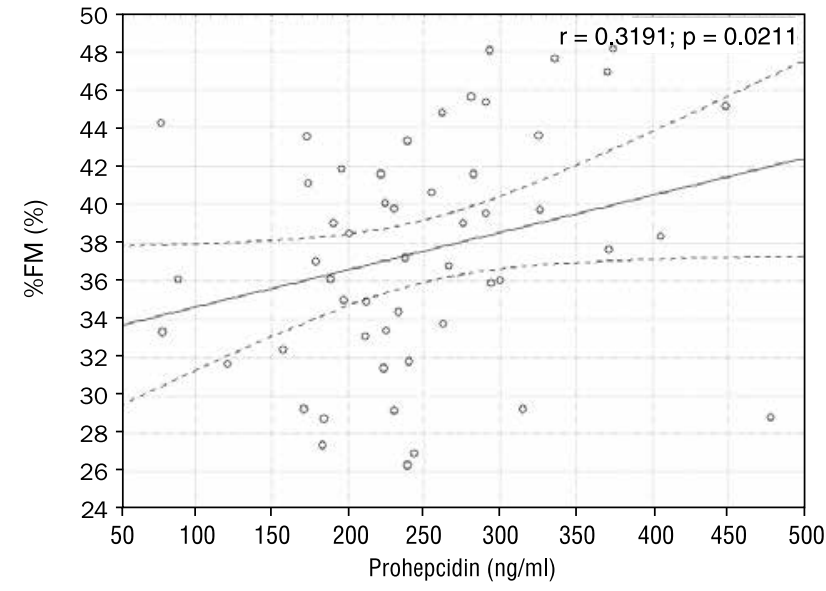

Figure 1. Spearman's correlation analysis of serum prohepcidin with \%FM in the group of obese individuals. \%FM — fat mass percentage; $p$ - significance level, Spearman $r$

Rycina 1. Analiza korelacji Spearmana pomiędzy surowicza prohepcydyna a \%FM w grupie otylych osób

obesity was defined based on the individual values of the percentage of body fat (Durnin and Wormsley formula) [25].

An obesity impact on the prohepcidin level was observed for the first time by Lainé et al., who reported that obese women with classical haemochromatosis do not have a phenotypic expression of the disease. They suggested that the adipose tissue, via a yet unknown mechanism involving hepcidin, can affect iron homeostasis [30]. This hypothesis was proven a year later by Bekri et al.'s research on the in vitro human adipocytes culture [5]. These authors discovered that hepcidin is a pro-inflammatory adipokine having great importance in sideropenia development in obese patients. They observed increases of hepcidin mRNA level and hepcidin concentration, in adipose tissue. Additionally, hepcidin mRNA expression was observed to positively correlate with IL- 6 and C-reactive protein concentrations, and to increase in the adipose tissue of considerably obese patients [5]. A complementary study was performed by Chung et al., where it was demonstrated that a line of human hepatoma cells [HuH7] treated with leptin resulted in the increase of hepcidin expression, depending on both exposition time and the leptin dosage [6]. Leptin, a hormone secreted by the white adipocytes, up-regulated hepcidin gene expression by means of leptin receptor [Ob- $\mathrm{Rb}$ receptor] connected to the JAK2/ /STAT3 cell signalling pathway [6].

In the present study, we investigated serum prohepcidin concentration and iron status indices in obese elderly individuals. We observed that $62 \%$ of obese persons had normocytic or microcytic anaemia. Our findings seem to agree with recent studies which indicate that anaemia in the elderly is a common medi- 
cal problem [31]. Epidemiological studies show that the prevalence of anaemia increases with age, with a marked increase above the age of 60 [32].

In our study, we observed significantly increased circulating prohepcidin in obese individuals compared to non-obese. Our findings seem to agree with the observations of Tussing-Humphreys et al. [33] who reported that obese premenopausal women have significantly higher serum hepcidin levels compared to nonobese women with similar serum parameters of iron status. Also del Giudice et al. [34] and Sanad et al. [35], in studies carried out in children aged 7-11 years, observed a significantly higher concentration of hepcidin in the obese. The results suggest that body fat content does have an impact on prohepcidin and hepcidin concentration, and therefore on iron homeostasis. A strong argument in support of this thesis is a statistically significant correlation between prohepcidin and fat mass percentage $(\% \mathrm{FM})$ observed in the whole group of obese individuals. Increased prohepcidin concentration in obesity can be explained in the most part as a result of its synthesis by a large amount of adipocytes. In addition, we should not exclude a chronic low-grade inflammation state inducing prohepcidin production. In our preliminary study, CRP was only slightly elevated in the group of obese people with anaemia. However, ferritin was increased in all obese individuals.

According to up-to-date research, the main factors regulating hepcidin expression in the liver are the stimuli signalling increased erythropoiesis i.e. hypoxia, and low transferrin saturation [20-21, 36-37].

The crucial problem for research, as well as clinical purposes, is whether this regulatory mechanism occurs in all cells involved in hepcidin production (including adipocytes) or is limited to hepatocytes. Bekri et al. established the lack of a positive feedback mechanism within the adipose tissue to control hepcidin secretion as a reaction to a low transferrin saturation. This mechanism has been observed only in the liver cells colony [5]. On the other hand, the lack of restraining impact of hypoxia on hepcidin expression in cardiomyocytes of rats was observed by Merle et al. In this study, the researchers noticed that hypoxia resulted in a significant increase of hepcidin mRNA levels and the concentration of the hormone itself, within the cardiac muscle. In contrast, the liver hepcidin expression decreased as a reaction to hypoxia [37]. All the results suggest that factors related to anaemia, such as tissue hypoxia and a decrease in transferrin saturation, have a negative effect on hepcidin production only in the hepatocytes, and that the regulation of hepcidin expression is possibly tissue-specific. Research indicates that hepcidin

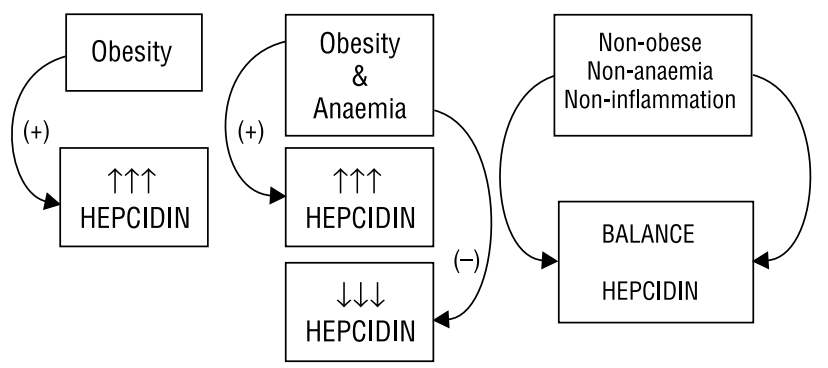

Figure 2. Diagram of impact of obesity and anaemia on serum hepcidin levels

Rycina 2. Schemat oddziatywania otyłości $i$ anemii na poziom surowiczej hepcydyny

expression in adipose tissue is probably stimulated rather by inflammatory stimuli than by iron [38].

According to our research, obese individuals with anaemia had significantly lower iron levels and increased EPO as a result of induced erythropoiesis, secondary to iron deficiency in its active metabolic pool. In this group, we observed significantly lower prohepcidin levels compared to obese individuals without anaemia, but higher compared to non-obese volunteers.

This observation may have important clinical implications, i.e. it is well known that hepcidin expression is more than 100-700-fold higher in hepatocytes than in adipocytes $[18,33]$. However, when adipose tissue mass is significantly increased, 'adipose tissue-derived pool of hepcidin' becomes relevant. Analysing the results of previous studies [5, 33-35, 39] it can be concluded that obesity, especially abdominal, may be associated with increased systemic hepcidin concentrations and iron dysregulation. In this case, anaemia accompanied by central obesity can have a negative impact on the course of the disease as well as the effectiveness of its treatment.

Worth mentioning in our current study is the fact that there was no difference in prohepcidin concentration between obese patients with anaemia and the control group (non-obese without anaemia). We suggest that two factors may have an impact on prohepcidin production in this study group (II): obesity and anaemia. Obesity, as we concluded in our previous study, increases prohepcidin concentration [40]. In contrast, anaemia related factors decrease hepatic prohepcidin expression [20, 21, 36, 37]. Such interaction, two oppositely acting factors, may lead to a state of balance in the level of circulating hepcidin (Fig. 2). As a result, in our group of obese patients with anaemia, prohepcidin levels were similar to values observed in the control group (non-obese without anaemia).

A potential limitation of our preliminary study is the fact that we have measured a prohormone (prohepci- 
din) of an active peptide (hepcidin). Further studies including quantification of hepcidin are needed to completely clarify the relative impact of adipose tissue on circulating hepcidin concentrations. Future studies should be conducted on comparatively larger populations of obese elderly patients.

It would also be very interesting to investigate whether long-term weight loss reduces inflammation and hepcidin concentration, consequently improving iron status in obese patients.

\section{Conclusion}

The results of our study suggest that obesity increases prohepcidin levels in elderly patients. Moreover, the coexistence of obesity and anaemia reduces prohepcidin levels to values observed in elderly non-obese patients without anaemia.

\section{References}

1. Pinhas-Hamiel O, Newfield RS, Koren I et al. Greater prevalence of iron deficiency in overweight and obese children and adolescents. Int J Obes Relat Metab Disord 2003; 27: 416-418.

2. Farahani P, Chiu S, Bowlus CL, Boffelli D et al. Obesity in BSB mice is correlated with expression of genes for iron homeostasis and leptin. Obes Res 2004; 12: 191-204

3. Nead KG, Halterman JS, Kaczorowski JM et al. Overweight children and adolescents: a risk group for iron deficiency. Pediatrics 2004; 114: 104-108.

4. Lecube A, Carrera, A Losada E et al. Iron deficiency in obese postmenopausal women. Obesity 2006; 14 : 1724-1730.

5. Bekri S, Gual P, Anty R et al. Increased adipose tissue expression of hepcidin in severe obesity is independent from diabetes and NASH. Gastroenteroogy 2006; 131: 691-693.

6. Chung B, Matak P, McKie AT et al. Leptin Increases the Expression of the Iron Regulatory Hormone Hepcidin in HuH7 Human Hepatoma Cells. J Nutr 2007; 137: 2366-2370.

7. Yanoff LB, Menzie CM, Denkinger B et al. Inflammation and iron deficiency in the hypoferremia of obesity. Int J Obes 2007; 31: 1412-1419.

8. Young VR. Macronutrient needs in the elderly. Nutr Rev 1992; 50: 454-462.

9. Rosen ED, Spiegelman BM. Adipocytes as regulators of energy balance and glucose homeostasis. Nature 2006; 444: 847-853.

10. Lago F, Dieguez C, Gómez-Reino J et al. Adipokines as emerging mediators of immune response and inflammation. Nat Clin Pract Rheumatol 2007; 3: 716-724

11. Nemeth E, Tuttle MS, Powelson J et al. Hepcidin Regulates Cellular Iron Efflux by Binding to Ferroportin and Inducing Its Internalization. Science 2004; 306: 2090-2093.

12. Laftah AH, Ramesh B, Simpson RJ et al. Effect of hepcidin on intestinal iron absorption in mice. Blood 2004; 103: 3940-3944.

13. Knutson MD, Oukka M, Koss LM et al. Iron release from macrophages after erythrophagocytosis is up-regulated by ferroportin 1 overexpression and down-regulated by hepcidin. Proc Natl Acad Sci U S A 2005 102: 1324-1328.

14. Rivera S, Liu L, Nemeth E et al. Hepcidin excess induces the sequestration of iron and exacerbates tumor-associated anemia. Blood 2005; 105: 1797-1802.

15. Weinstein DA, Roy CN, Fleming MD et al. Inappropriate expression of hepcidin is associated with iron refractory anemia: implications for the anemia of chronic disease. Blood 2002; 100: 3776-3781.
16. Yamaji S, Sharp P, Ramesh B et al. Inhibition of iron transport across human intestinal epithelial cells by hepcidin. Blood 2004; 104: 2178-2180.

17. Park $\mathrm{CH}$, Valore EV, Waring AJ et al. Hepcidin, a urinary antimicrobial peptide synthesized in the liver. J Biol Chem 2001; 276: 7806-7810.

18. Krause A, Neitz S, Magert HJ et al. LEAP-1, a novel highly disulfidebonded human peptide, exhibits antimicrobial activity. FEBS Lett 2000; 480: $147-150$.

19. Hunter HN, Fulton DB, Ganz T et al. The solution structure of human hepcidin, a peptide hormone with antimicrobial activity that is involved in iron uptake and hereditary hemochromatosis. J Biol Chem 2002; 277: 37597-37603

20. Benedict C, Ghio AJ, Gehring H et al. Transient hypoxia and downregulation of circulating prohepcidin concentrations in healthy young men. Haematologica 2007; 92: 125-126.

21. Leung PS, Srai SK, Mascarenhas Met al. Increased duodenal iron uptake and transfer in a rat model of chronic hypoxia is accompanied by reduced hepcidin expression. Gut 2005; 54: 1391-1395.

22. Hadley KB, Johnson LK, Hunt JR. Iron absorption by healthy women is not associated with either serum or urinary prohepcidin. Am J Clin Nutr 2006; 84: 150-155.

23. Nicolas G, Bennoun M, Porteu A et al. Severe iron deficiency anemia in transgenic mice expressing liver hepcidin. Proc Natl Acad Sci 2002; 99: 4596-4601.

24. Szczygieł B. Metody oceny stanu odżywienia chorych w szpitalach In: Dzieniszewski J, Szponar L, Szczygieł B, Socha J (eds.). Podstawy naukowe żywienia w szpitalach, IŻŻ, Warszawa, 2001: 324-339.

25. Heymsfield SB, Williams PJ. Nutritional assessment by clinical and biochemical methods. In: Shils, ME, Young VR, Febiger L (eds.). Modern nutrition in health and disease. Philadelfia, Ed. $7^{\text {th }} ; 1998 ; 817-860$.

26. Villareal DT, Apovian CM, Kushner RF et. al. Obesity in older adults: technical review and position statement of the American Society for Nutrition and NAASO, The Obesity Society. Am J Clin Nutr 2005; 82: 923-934.

27. Willett WC, Dietz WH, Colditz GA. Guidelines for healthy weight. N Engl J Med 1999; 341: 427-434.

28. Ritz P. Editorial: Obesity in the elderly: should we be using new diagnostic criteria? J Nutr Health Aging. 2009; 13:168-169.

29. Sorkin JD, Muller DC, Andres R. Longitudinal change in height of men and women: implications for interpretation of the body mass index: the Baltimore Longitudinal Study of Aging. Am J Epidemiol 1999; 150: 969-977.

30. Lainé F, Jouannolle A, Morcet J et al. Phenotypic expression in detected C282Y homozygous women depends on body mass index. J Hepatol 2005; 43: 1055-1059.

31. Guralnik JM, Ershler WB, Schrier SL et al. Anemia in the Elderly: A Public Health Crisis in Hematology. Hematology — Am Soc Hematol Educ Program 2005: 528-532.

32. Balducci L. Epidemiology of Anemia in the Elderly: Information on Diagnostic Evaluation. J Am Geriatr Soc 2003; 51: 2-9.

33. Tussing-Humphreys LM, Nemeth E, Fantuzzi G et al. Elevated systemic hepcidin and iron depletion in obese premenopausal females. Obesity (Silver Spring) 2010; 18: 1449-1456.

34. del Giudice EM, Santoro N, Amato A et al. Hepcidin in obese children as a potential mediator of the association between obesity and iron deficiency. J Clin Endocrinol Metab 2009; 94: 5102-5107.

35. Sanad M, Osman M, Gharib A. Obesity modulate serum hepcidin and treatment outcome of iron deficiency anemia in children: a case control study. Ital J Pediatr 2011; 37: 34-40.

36. Nicolas $G$, Chauvet $C$, Viatte $L$ et al. The gene encoding the iron regulatory peptide hepcidin is regulated by anemia, hypoxia, and inflammation. J Clin Invest 2002; 110: 1037-1044

37. Merle U, Fein E, Gehrke SG et al. The iron regulatory peptide hepcidin is expressed in the heart and regulated by hypoxia and inflammation. Endocrinology 2007; 148: 2663-2668.

38. Vokurka M, Lacinova Z, Kremen J et al. Hepcidin Expression in Adipose Tissue Increases during Cardiac Surgery. Physiol Res 2010; 59: 393-400.

39. Tussing-Humphreys L, Frayn KN, Smith SR et al. Subcutaneous adipose tissue from obese and lean adults does not release hepcidin in vivo. Scientific World Journal 2011; 11: 2197-206.

40. Przybyszewska J, Zekanowska E, Kedziora-Kornatowska K et al. Prohepcidin and iron metabolism parameters in the obese elderly patients with anemia. J Nutr Health Aging 2011; 15: 259-264. 